DOI: $10.17805 /$ zpu.2017.3.15

\title{
Китайская парадигма восточноазиатской интеграции
}

\author{
В. И. БАЛАКИН \\ МОСКОВСКИЙ ГУМАНИТАРНЫЙ УНИВЕРСИТЕТ
}

\begin{abstract}
Американская администрация и японское правительство официально не рассматривают КНР в качестве главного противника, однако практически все международные эксперты полагают, что могучее китайское государство последовательно вырастает в серьезного конкурента за влияние в Восточноазиатском регионе. Среди специалистов считается, что для США и Японии исключительно важным фактором является необходимость иметь исключительно ясную концепцию взаимоотношений с Китаем на ближайшие 15-20 лет. Регионализация в Восточной Азии привела ее участников к поискам противовесов и попыткам создания некоего равновесия с помощью гармонизации международных отношений. Китайская сложившаяся формула восточноазиатской интеграции содержит весьма значительное количество вполне убедительных аргументов в пользу важности заметного усиления региональной составляющей. Та же Япония, например, не хочет сдаваться на милость Китая и пытается противопоставить общественное мнение практически всех стран Восточной Азии, ощущающих серьезную тревогу в отношении непредсказуемых последствий усиливающегося китайского доминирования в Восточноазиатском регионе. Восточноазиатские государства внимательно следят за динамикой роста военной мощи КНР, особенно в ее новом количественном и качественном выражении.
\end{abstract}

По оценкам международных экспертов, Китай в силу своего заметно растущего экономического, демографического, военного и политического потенциала становится одним из самых влиятельных игроков на азиатской сцене, а в перспективе способен реально доминировать во всех знаковых азиатских делах.

Ключевые слова: КНР; Китай; Япония; регионализация; региональное соперничество; региональное лидерство; восточноазиатская интеграция; Восточноазиатское сообщество

\section{BВЕАЕНИЕ}

$\prod^{\circ}$ о оценкам международных экспертов, формирующаяся китайская модель восточноазиатской интеграции уже сегодня представляет собой достаточно привлекательный феномен, вызывающий реальный интерес у государств региона. С точки зрения общей теории региональной интеграции последовательное формирование элементов наднациональной государственности в Восточной Азии демонстрирует весьма 
убедительный пример диалектического развития региона, представляющий собой единство и борьбу противоположностей в виде объективного противоречия между нараставшей в последние десятилетия глобализацией и активно сопротивлявшейся ей регионализацией. Глобализирующийся мир до последнего времени внешне весьма привлекал международную общественность активным становлением внешне весьма позитивных взаимозависимостей, позволяющих достаточно эффективно решать многочисленные политические проблемы, как правило, связанные с застарелыми традиционалистскими фобиями. Вместе с тем региональные особенности постоянно дают о себе знать в виде исторически сложившихся периферийных отношений соседствующих стран, для которых собственные суверенитеты вполне укладываются в давно утвердившиеся направления регионального сотрудничества, при этом активно стимулирующие тенденции к углубляющейся регионализации, т. е. к автономному формированию и развитию вполне устоявшихся хозяйственных территорий. В данной связи можно констатировать, что китайская модель восточноазиатской интеграции, воссоздающая в той или иной мере общее цивилизационное пространство в зоне традиционных интересов Китая, стало некой защитной реакцией Пекина на мощный напор со стороны США и их главного регионального союзника в лице Японии, постоянно пытающихся нейтрализовать усилия КНР сделать решающий экономический рывок, подкрепляя его устойчивым ростом мощной военной составляющей своего совокупного национального потенциала (Terada, 2015: 91).

Во всем мире внимательно следят за динамикой роста военной мощи КНР, особенно в ее новом количественном и качественном выражении. Численность вооруженных сил Китая даже после масштабных сокращений остается самой крупной в мире. Кроме того, китайское правительство делает все возможное, чтобы нарастить критическую массу новейших боевых систем, стоящих на вооружении китайских армии, авиации и флота, отладить оснащенность и подготовленность органов управления, развить военную инфраструктуру и технологический потенциал оборонной промышленности для успешного решения любых самых сложных задач в современных высокотехнологичных войнах, особенно, что характерно, за пределами китайской территории. Военная доктрина КНР в пределах Восточной Азии предусматривает прежде всего присоединение Тайваня на условиях, выдвигаемых самим Пекином, и установление эффективного контроля над спорными островами в Южно-Китайском (архипелаг Спратли) и Восточно-Китайском (острова Сэнкаку) морях. По оценкам японских экспертов, КНР на сегодня в силу своего растущего экономического, демографического, военного и политического потенциала становится одним из самых влиятельных игроков на азиатской сцене, а в перспективе способна реально доминировать во всех знаковых азиатских делах (Matsuyi, 2011: 4).

Восточноазиатская интеграция для Китая в значительной степени является ареной международной демонстрации растущей национальной мощи, уверенности в своих силах, серьезным аргументом в претензиях на политическое лидерство. Руководство КНР осознает, что традиционное китайское государство находится в некоторой «поворотной точке», когда происходит зримый перелом в геополитическом раскладе сил: практически обваливается уже полностью сложившийся по итогам Второй мировой войны миропорядок, вызревают новые объективные тенденции, мало зависящие от воли «великих держав», которые пока абсолютно не способны претворить в реальность принцип «вселенской справедливости». На глазах исчезает универсальность ценностных категорий, еще вчера не оспаривавшихся практически никем и провозгла- 
шавших категорию национальной государственности в качестве весьма устаревшей формы существования народов во всемирной истории. Государственность в Китае никогда не обсуждалась с точки зрения некоего утилитарного механизма бюрократического управления, напротив, категория государственности всегда представляла собой и будет представлять абсолютно сакральное явление, оберегающее традиции, в рамках которых накапливаются огромные творческие силы, позволяющие нации сохраняться и интегрировать в себя новые составные части (Dent, 2008: 43). Китайское руководство и впредь намерено более активно поддерживать только те расширяющиеся региональные интеграционные инициативы, которые не будут противоречить устоявшимся двусторонним отношениям с ведущими восточноазиатскими партнерами.

\section{ЯПОНИЯ КАК ОСНОВНОЙ СОПЕРНИК КИТАЯ В ВОСТОЧНОЙ АЗИИ}

Считается, что для Японии всегда исключительно важным являлось иметь ясную концепцию взаимоотношений с Китаем на перспективу 15-20 лет. В данной связи хотя Токио официально не рассматривает КНР в качестве главного противника, однако практически все японские эксперты полагают, что могучее китайское государство вырастает в серьезного конкурента за влияние в ключевом Восточноазиатском регионе. Китай безусловно способен крайне осложнить реализацию долгосрочных японских национальных интересов в Восточной Азии. Главным же стабилизирующим фактором все более реально выступают двусторонние китайско-японские отношения в экономической сфере, которые, несмотря на все имеющиеся серьезные разногласия, до сих пор всегда носили, носят и будут носить вполне реальный взаимозависимый, исключительно взаимовыгодный и весьма многомерный характер (Zhang, 2012: 111). В последовательно и уверенно набирающих серьезную силу процессах восточноазиатской региональной интеграции присутствует немало положительных моментов, но вместе с тем появляются и новые довольно серьезные вызовы, как то: определенное ущемление государственного суверенитета, существенный рост влияния крупных внерегиональных транснациональных корпораций, монополизация локальных финансовых рынков, ужесточение конкуренции, затрагивающей не только экономику, но и политику, дипломатию, военные аспекты региональной безопасности.

Государственный суверенитет в Китае представляет собой некую сакральную категорию национального самосознания, поскольку он всегда обеспечивал идеологическую преемственность в рамках китайской цивилизации. Во многом это означает укрепление сложившегося государственного устройства, что подтверждает приверженность нынешнего китайского руководства имперской идее и стремление поставить жесткие пределы распространению в рамках страны противоестественного западного либерального сознания. В соответствии с известной концепцией Мао Цзэдуна одной из главных целей учреждения КНР было, есть и будет оставаться создание богатого и сильного китайского государства, которое никогда не согласится на легализацию серого бизнеса коррупционной номенклатуры и, более того, из-за страха потерять все вынудит ее начать вкладывать многомиллиардные инвестиции в народное хозяйство собственной страны (Brown, 2013: 84). Председатель КНР Си Цзиньпин является откровенным прагматиком до мозга костей, и он понимает, что ему придется выбирать между солидарностью с влиятельными коррупционерами в партийной среде, имеющими серьезную поддержку финансовой элиты США и готовыми начать конвертировать свои капиталы в реальную власть над Китаем, и своей ролью в китайской истории как создателя современного могучего национального государст- 
ва XXI в. Это крайне серьезный вызов первому лицу в руководстве КНР, но любой компромисс по вопросу о судьбе китайской государственности абсолютно чужд Си Цзиньпину, и отсюда не следует ожидать от него каких-либо уступок либеральным силам внутри страны и на Западе.

Возникающие вызовы в регионе Восточной Азии заметно обостряют традиционные и порождают новые угрозы. Сепаратизм, политический и религиозный экстремизм, сопутствующие им незаконный оборот оружия и наркотрафик получают все большее распространение. Однако при всех разногласиях и в Китае, и в других странах Восточной Азии правительства понимают, что ни одно государство, даже очень сильное, не способно справиться с названными выше угрозами в одиночку, а потому весьма нужны скоординированные усилия всех государств Восточноазиатского региона. В этом проявляется, по мнению многих международных экспертов, особенность взаимосвязи экономики, политики и ясной военной стратегии в реальных условиях Восточной Азии (Xia, 2006: 115). Пользуясь зрелыми плодами регионализации, ее субъекты видят вполне определенные негативные стороны, суть которых в том, что далеко не у всех государств в Восточной Азии долгосрочные национальные интересы реально совпадают, а значит, при разрешении глубинных противоречий не исключаются серьезные эксцессы, вплоть до применения грубой военной силы.

Последнего стараются всеми силами избежать практически все участники восточноазиатского интеграционного процесса, ориентируясь прежде всего на достижение вариативных компромиссов, содержание которых не только учитывает традиционный менталитет элит государств конфуцианской цивилизации, но и в значительной степени сопрягает особенности переговорных позиций участников. Именно фактор сопряжения национальных особенностей позволил идее восточноазиатской интеграции возникнуть в Северо-Восточной Азии. В Юго-Восточной Азии сравнительно небольшие страны значительно легче нашли общий язык и уже давно оставили за рамками реально достижимых компромиссов любые политические мотивы, на которых могли бы сыграть крупные государства Северо-Восточной Азии: Китай, Япония, Республика Корея, а также мощные внешние игроки, такие как США и Россия (Xu, 2003: 4). Следует отметить, что роль внешних игроков объективно достаточно велика и выражается прежде всего в соблазне реальных участников восточноазиатской интеграции использовать в собственных интересах сложившиеся принципиальные противоречия в современных российско-американских отношениях. Принято рассматривать процессы региональной интеграции в качестве объекта исключительно правового регулирования на основе международных договоров, однако в реальности интеграционные объединения являются не чем иным, как продуктом волеизъявления наиболее мощных и сложившихся государственностей. Применительно к Восточной Азии влияние России и США по объективным причинам никогда не сможет переломить доминирование Китая в регионе, поскольку оно проистекает из тысячелетних цивилизационных факторов, изменить кодировку которых не под силу даже самому мощному экономическому воздействию.

Процесс регионализации в Восточной Азии привел ее участников к активным поискам эффективных противовесов и попыткам создания некоего регионального равновесия с помощью целенаправленной гармонизации международных отношений. Восточноазиатский регион не ограничивается реальным географическим пространством, он стал весьма многомерным. В процессе регионализации окончательно побеждает то государство, которое способно наиболее әффективно и целеустремленно ис- 
пользовать на практике реальный геополитический, геоэкономический и цивилизационный потенциал для ускорения оборачиваемости финансового, промышленного и торгового капитала (Воeisyo, 2011: 18). Регионализацию международных отношений в том же Китае рассматривают как реальную альтернативу глобализации, крайне упорно продвигавшуюся до самого последнего времени Соединенными Штатами Америки. Аавно и прочно сложившаяся американская внешнеполитическая доктрина представляет глобализацию объективным процессом в международных отношениях, самым высшим этапом интернационализации, и именно в этом принципиальное различие между китайским и американским подходами.

Глобалистские воззрения на интеграционные процессы в той или иной мере господствуют сегодня практически во всех теоретических выкладках, рассматривающих насильственное объединение человечества в качестве и, по сути дела, единственной реальной альтернативы тотальному разрушению существующей земной цивилизации (Zhang, 2006: 173). Влиятельные адепты вульгарного экономизма весьма прямолинейно, а главное - настойчиво продвигают позитивные аспекты глобализации (а они безусловно присутствуют), исходя из последовательно нарастающего расширения разнообразных региональных хозяйственных связей. По мере их упрочения на глобальном уровне создается унифицированная материя широкого кооперационного сотрудничества, которое постепенно превращается в саморегулирующуюся геополитическую общность. Эта общность начинает активно функционировать вполне независимо от заинтересованных национальных государств. Здесь возникает объективное противоречие, суть которого сводится к дилемме властного приоритета, когда устоявшаяся государственность абсолютно не хочет мириться с внешней юрисдикцией над собственными юридическими и физическими лицами. Глобализация в принципе абсолютно чужда национальному государству, поскольку неизбежно превращает его в обслуживающий формат наднациональной власти, ясно нацеленной на обезличивающую унификацию политического суверенитета любой страны. Именно Китаю подобный исключительно универсалистский подход к национальной государственности видится неприемлемым, особенно в свете намечающегося обострения отношений с администрацией США, определенно нацелившейся реально проверить устойчивость китайской внешнеполитической позиции.

\section{ВОСТОЧНАЯ АЗИЯ В ИНТЕГРАЦИОННОЙ СТРАТЕГИИ КИТАЯ}

Китайская формула восточноазиатской интеграции преследует в качестве главной цели достижение мощного кумулятивного эффекта при формировании регионального геоэкономического полюса. Такой подход заметно отличается от общей стратегии США в Восточной Азии, предусматривающей ограничение любых национальных суверенитетов практически во всех сферах: политике, экономике, финансах и культуре. В руководстве КНР постепенно наступает осознание того, что только формирование надгосударственных образований под полным китайским контролем в Восточноазиатском регионе может стать оптимальной интеграционной моделью, способной әффективно реагировать на внешние и внутренние политические вызовы (Сао, 2015: 54). В прошлом такими образованиями были империи, а сегодня эту роль выполняют государства-цивилизации, одним из которых несомненно является Китай. Современная формула китайской восточноазиатской интеграции становится важным фактором внешней и внутренней политики КНР, выражающимся в сочетании геополитики, геоэкономики и культурных особенностей региона. 
Аля Китая геополитическая ситуация в Восточной Азии выглядит на настоящий момент следующим образом: межгосударственные отношения в Восточноазиатском регионе уже нельзя считать региональным вариантом глобализации; фактически в Восточной Азии существует лишь один центр силы как регионального, так и глобального уровня, и этим центром силы является КНР; на восточноазиатском геополитическом пространстве Китай выступает сегодня в качестве единственного системного интегратора (Chen, Lung-chu, 2015: 28). Именно Пекин в XXI в. превратил Восточную Азию в один из трех главных центров мира, прежде всего за счет высоких темпов экономического роста, а также динамичного наращивания объемов внутрирегиональной и внерегиональной торговли, осуществления огромных целевых государственных и частных инвестиций в НИОКР. Основным отличием сложившейся китайской интеграционной модели для Восточной Азии стало формирование региональной геополитической системы с собственной заданной иерархией субрегионов и исключительно специфическим характером сложившихся межгосударственных связей между ними, ориентированных на экспортоориентированные механизмы. Уже сегодня по факту КНР создал в Восточноазиатском регионе, по сути дела, единую систему закулисного управления, когда не только и не столько экономическая составляющая играет определяющую роль, но в большей степени желательным китайскому руководству представляется достижение эффективного доминирования на геополитическом уровне. Одновременно китайские власти прилагают серьезные усилия, чтобы обстановка внутри страны оставалась сравнительно стабильной, предсказуемой, позволяющей не допустить эрозию влияния Китая в Восточноазиатском регионе (Gehler, Rollinger, 2014: 515-535).

Международные эксперты всерьез рассматривают нынешний подъем политической активности Пекина в Восточной Азии как важный феномен, призванный консолидировать китайское общество на патриотической основе, показать, что и в дальнейшем КНР не остановится перед принятием любых адекватных мер для защиты своих национальных интересов (Mizuno, 2012: 3). Аействия Китая в Южно-Китайском море вряд ли отвратят страны Юго-Восточной Азии от тесного экономического сотрудничества с КНР, поскольку всем сторонам в регионе понятна антиамериканская направленность данных действий, ставящих главной целью показать наличие серьезных препятствий для беспроблемного возвращения США в Восточную Азию. Имеющее место обострение отношений с Японией также носит весьма поверхностный характер, так как крупнейшие японские корпорации рассматривают свое устоявшееся присутствие на китайском рынке в качестве существенной гарантии против второй волны последнего финансового кризиса. Жесткая реакция Китая на территориальные притязания со стороны той же Японии позволила консолидировать китайско-тайваньские отношения, внести в них элементы общего патриотизма. В сложившейся ситуации Соединенным Штатам Америки уже вряд ли удастся разыграть во взаимоотношениях с КНР так называемую тайваньскую карту.

Тем не менее попытки выработать такой курс уже видны во внешнеполитических планах новой администрации США, которая пока только на словах, но уже пытается подкрепить надежды нынешнего тайваньского руководства завоевать поддержку крупных держав в международном признании острова независимым государством. Поиск путей достижения полного государственного суверенитета Тайваня представляет для интеграционной стратегии КНР в Восточной Азии реальную геополитическую угрозу, поскольку реально порождает так называемый местный территориаль- 
ный национализм. У значительной части тайваньского населения присутствует убежденность, что не только управлявшая островом 50 лет (1895-1945 гг.) японская колониальная администрация, но и передислоцировавшееся на Тайвань в 1949 г. гоминдановское правительство Чан Кайши мало чем отличаются друг от друга и являются чуждыми тайваньской национальной идентичности. Нынешнее правительство Тайваня выступает весьма критически к своим оппозиционным оппонентам из Гоминдана, отрицая их надежду на восстановление в перспективе единого Китая, и находит в этом серьезную поддержку в Токио. Серьезно волнуется пекинское руководство по поводу стремления Тайбэя встать на путь достижения государственного суверенитета, которое выражается в желании самостоятельно выстраивать свое государственное развитие, а также искать свое собственное место в процессах региональной интеграции.

В данной связи возникает обоснованный вопрос о судьбе формирующегося Восточноазиатского сообщества. Предпринимающиеся попытки в восточноазиатской интеграции повторить путь, пройденный Европейским союзом, обречены, по мнению руководителей КНР, на неудачу, а вот идея сформировать общее экономическое пространство в регионе выглядит вполне реальной (Sugimoto, 2009: 33). Китай скореe всего будет продолжать настойчиво стремиться к созданию чисто экономического объединения, в котором официально не предполагается учреждение централизованного механизма принятия ключевых политических решений. Абсолютно ясно, что централизация все равно постепенно станет вызревать, но именно вызревать, а не напрямую вводиться специально. Аиалектика китайской формулы восточноазиатской интеграции подразумевает вовлечение в процесс региональных партнеров через систему очевидных экономических выгод, от которых просто нельзя будет отказаться.

Моделирование региональной интеграции в Восточной Азии для Китая представляет собой сложный процесс, покоящийся на философских традициях, позволявших на протяжении тысячелетий сохранять особую категорию государственности, которая всегда опиралась на устоявшийся конфуцианский принцип формирования горизонтальной гармонии и неуклонного восхождения $к$ небесной симфонии. "Горизонтальная гармония» изначально эгалитарна и нормативна, поскольку исходит из принципов традиционного образа жизни и предполагает постоянное развитие национальной государственности, а также порождает национальную по духу институализацию любых интеграционных процессов. В результате появляется официальная идеология, призванная воспитывать правящую элиту, которая активно занимается самосовершенствованием и упорно стремится к симфонии духа, как того жестко предписывало широко распространенное в Восточной Азии объективно-идеологическое неоконфуцианское учение, провозглашавшее следующий философский постулат: «Только путем последовательного устранения собственных индивидуальных желаний человек может реально достичь состояния, когда принципы Неба интегрированно проявляются в человеке, а затем и в обществе в своем полном совершенстве» (Hayashi, 1930: 203). Восточноазиатская интеграция в данном конкретном случае с философской точки зрения рассматривается как естественное право местных государств на цивилизационное единение, исходя из конфуцианских принципов «небесной симфонии», накрепко объединяющих сложившиеся самостоятельные государственности. Иными словами, названный перманентный процесс можно назвать неким складывающимся «восхождением» к объективной диалектической взаимозависимости и субъективным усилиям по целенаправленному достижению естествен- 
ной социальной гармонии, как это продекларировано в рамках того же Евросоюза (Juncer, 2014: 9).

\section{ВОСПРИЯТИЕ КИТАЙСКОЙ ИНТЕГРАЦИОННОЙ МОАЕАИ В ВОСТОЧНОЙ АЗИИ}

Восточноазиатская формула региональной интеграции понимается как замкнутая органическая единица, имеющая качественные характеристики макросистемы, т. е. цивилизации. Макросистема обладает внутренней согласованностью составляющих ее элементов, а также неким внутренним равновесием. Это равновесие воплощает в себе соответствующие общие принципы, единые «культурные конфигурации», вполне специфические региональные идеи и «коллективный дух». В китайской идее интеграции следует отметить ее культурологическую интерпретацию, под которой в Китае понимают общую социокультурную реальность, взаимозависимость между элементами интегрирующей системы, обеспечивающей ее внутреннее единство, ее самосохранение, гармоничное функционирование, устойчивость в критических ситуациях и диалектическую стабильность. По мнению китайских экспертов, предусматривается наличие неких объективных норм, которые интегрирующимся субъектам надлежит принять, и сделать это придется путем безусловного признания правил общего регионального пространства (Motegi, 2013: 49).

Пока трудно понять, что способно побудить обремененные тяжелым историческим опытом восточноазиатские страны встать на путь региональной интеграции, однако главным является то, каким образом это будет осуществляться на практике, так как отчетливо заметным становится желание внешних региональных игроков (прежде всего США) не допустить выхода Восточной Азии из зоны своего вполне сложившегося влияния. Американское политическое присутствие в Восточноазиатском регионе носит наднациональный характер и выстроено по так называемому европейскому образцу, когда США выполняют в Евросоюзе роль верховного арбитра и занимаются исключительно «высокой политикой», т. е. определяют главные параметры взаимодействия европейских государств, оставляя последним «политику низкого уровня», предусматривающую лишь строгое и четкое выполнение прямых указаний из Вашингтона (Helwig, 2015: 175). В Восточной Азии интеграционный процесс олицетворяется острым соперничеством Китая и США, основным трендом которого выступают попытки двух держав поставить под свой полный контроль взаимодействие внутренних и внешних геополитических факторов в регионе. Похоже, в данном объективном процессе преимущества все более концентрируются на стороне Пекина, который активно и весьма эффективно использует в своей региональной политике влиятельные общины зарубежных китайцев, обладающие существенными финансовыми, а значит, и политическими возможностями в Восточной Азии. Зарубежные китайцы достаточно сплочены национальной идеей и практически лишь внешне и по большей части формально подчиняются властям государств своего пребывания, полностью ориентируясь в собственных геополитических воззрениях на основополагающие идеи Большого Китая.

В данной связи китайские эксперты называют одной из основных проблем восточноазиатской интеграции «выборочную лояльность», т. е. особую политическую приверженность в каждый конкретный момент признанному лидеру, ориентацию на него сформировавшегося сообщества региональных суверенных государств. Отсюда региональная интеграция в Восточной Азии всегда подразумевала сильную зависимость 
от созданных лидером наднациональных органов управления, но никто из членов сообщества не готов до конца рассматривать себя частью целого, забыв о национальном суверенитете и интересах. Это представляет собой объективную реальность и побуждает руководство КНР искать нетрадиционные способы достижения солидарности в рамках вызревающего Восточноазиатского сообщества. Не исключается и реальное принуждение, основанное на схемах применения прямых и косвенных экономических санкций. При этом присутствующие в Восточной Азии многочисленные китайские общины успешно избегают подобных санкций, поскольку гарантированно выполняют предписания Пекина, воспринимая региональную интеграцию как свой цивилизационный долг (Bono, 2007: 115).

Современная китайская цивилизация проходит в настоящее время фазу самоутверждения и поэтому занимает все более жесткую международную позицию практически по всем региональным проблемам. Наличие колоссального человеческого потенциала в Китае, оживление менталитета Срединной империи порождают новые форматы регионального взаимодействия в Восточной Азии. Это взаимодействие представляет собой процесс двоякого рода: с одной стороны - наблюдается появление новых интеграционных конгломератов, а с другой - происходит формирование нетрадиционных линий противостояния (Yafuku, 2015: 6). Вместе с тем существует общая тенденция, в соответствии с которой имеет место весьма последовательное многомерное усовершенствование весьма активно вызревающего Восточноазиатского сообщества суверенных наций, заметно и существенно повышается его общая надежность как региональной әкономической системы. В то же время восточноазиатская интеграция развивается в едином противоречивом процессе, приобретая черты региональной группировки, принимающей на себя роль одного из главных субъектов мирового экономического развития.

Государства Восточноазиатского региона сегодня не только ищут реальную экономическую парадигму интеграции, но и пытаются нащупать потенциальные возможности политического согласования своих позиций. Идея нового международного правопорядка в Восточной Азии активно обсуждается в настоящее время в Китае, Японии и Республике Корея с акцентом на идентификацию стратегических приоритетов для каждой из названных стран. Имеющиеся точки зрения на новый восточноазиатский правопорядок содержат несколько аспектов, среди которых особого внимания заслуживают следующие: является ли Китай политическим лидером региона или политическое лидерство как таковое не может иметь места в силу глубоких противоречий между крупнейшими странами региона; какова будет роль США в Восточной Азии при новой американской администрации; будет ли достигнут американо-китайский компромисс на региональном уровне или сложившаяся после окончания холодной войны модель международных отношений в Азиатско-Тихоокеанском регионе сохранит свою значимость и не подвергнется пересмотру со стороны КНР в пользу концепции Великой Восточной Азии, не предусматривающей американского участия; не станет ли восточноазиатская интеграция прологом к формированию Китаем евразийского геополитического пространства от Шанхая до Цондона. Китайское руководство уже поставило названную выше повестку в свой геополитический реестр, тщательно прорабатывая последовательность действий. Более того, проводимые Пекином исследования касаются также отношений Китая с Россией и Евросоюзом прежде всего на предмет исключения какого-либо американского влияния на евразийские дела (Brink, 2012: 630). 
В данной связи Китай стремится выработать общие интеграционные подходы не только в экономической сфере, но и в весьма чувствительной сфере региональной безопасности (Watanabe, 2011: 21). Китайский интеграционный проект для Восточной Азии изначально предполагал разработку фундаментального документа в виде устава, где предполагалось записать такие положения, как отказ от оружия массового уничтожения и недопущение гонки вооружений. КНР также всегда стремилась найти общее понимание с партнерами по Восточноазиатскому сообществу в вопросе о декларируемом принципе невмешательства во внутренние дела друг друга. Китайскому правительству, например, абсолютно не нравятся требования Запада к Ассоциации стран Юго-Восточной Азии (ACEAН) осуществлять нажим на власти Мьянмы (Бирмы) с тем, чтобы они приступили к демократизации страны. Пекин дает ясно понять, что не потерпит никакого внерегионального воздействия на ситуацию в Восточной Азии, и особенно в зоне его исключительного влияния.

А такой зоной своих исключительных интересов руководство КНР считает формирующееся Восточноазиатское сообщество, которое Китай пытается выстроить, исходя из сложившихся принципов собственной государственности, но проявляя при этом максимальную осторожность, опирающуюся на древний конфуцианский принцип: серьезная опасность возникает тогда, когда сегодня государственность может быть одной, а завтра другой. Интеграционный процесс теоретически по форме выступает как межгосударственное конвенциональное правовое явление, однако на практике несет в себе существенную геополитическую подоплеку. Природа Восточноазиатского сообщества представляет собой мощный заряд функциональных взаимозависимостей между странами региона, при этом понять исходную функцию каждой из стран означает возможность спрогнозировать их реальные цели и глубинные национальные интересы. Последние как раз и представляют собой ныне сложившиеся государственности, которые можно рассматривать в виде самостоятельных систем, стремящихся к саморазвитию и объективно притягивающихся друг к другу (Tanaka, 2010: 9). В идеале для Пекина все же предпочтительнее одна функция, реализующаяся сразу по нескольким направлениям, и такую сложную функцию эффективнее всего выполняет наднациональная государственность, и Китай явно начинает постепенное движение в данную сторону.

В КНР движение к созданию Восточноазиатского сообщества сегодня воспринимается как постепенный отход от устоявшейся формулы ACEAH+3 (Китай, Южная Корея, Япония). Вступившее в силу 1 января 2010 г. соглашение о зоне свободной торговли между Китаем и АСЕАН позволило Пекину наглядно показать Сеулу и Токио серьезность его намерений единолично доминировать в процессах восточноазиатской интеграции. Быстро растущая совокупная государственная мощь Китайской Народной Республики отрезвляюще действует на ее корейских и японских конкурентов, оставляя им лишь возможность громогласно протестовать против некой нарастающей «китайской угрозы». Если в Японии еще надеются на какую-то мифическую «мягкую силу», способную повлиять на китайские власти, то в Республике Корея уже окончательно пришли к выводу относительно необходимости срочно искать для себя достойное место в региональных интеграционных планах Китая. Судя по всему, в ближайшей перспективе японское правительство станет свидетелем формирования устойчивого альянса в составе КНР, Республики Корея и АСЕАН, который в рамках китайской интеграционной формулы в полной мере распорядится дальнейшей судьбой Восточноазиатского сообщества (Којіма, 2011: 17). 
Однако Япония не хочет сдаваться на милость победителя в лице Китая и пытается противопоставить общественное мнение стран АСЕАН, ощущающих тревогу в отношении последствий китайского доминирования в Восточноазиатском регионе. Кроме того, у японского правительства остается надежда на глубокие союзнические отношения с Соединенными Штатами Америки, которые сами озабочены возрастанием мощи КНР и готовы предпринять самые радикальные меры по противодействию региональным планам Пекина. Антикитайские усилия японо-американского военно-политического альянса способны привлечь самых неожиданных сторонников из среды стран АСЕАН. Несмотря на официальные планы региональной интеграции, отдельные государства Юго-Восточной Азии не исключают возможности заключения выгодных двусторонних соглашений о свободной торговле как с Японией, так и с США. Начиная с Азиатского финансового кризиса 1997-1998 гг. в Восточной Азии стала вызревать идея создания Азиатского валютного фонда, инициатором которой была и остается Япония; для Китая названная идея может оказаться существенным препятствием на пути реализации его амбициозных планов, связанных с восточноазиатской интеграцией (Tanabe, 2005: 5).

\section{ЗАКАЮЧЕНИЕ}

Экономическая трансформация восточноазиатских стран пока не сопровождается общей технологической модернизацией. Мировой опыт показывает, что успешность любой интеграционной группировки и ее устойчивое развитие зависят от того, насколько она содействует распространению и производству новых товаров и услуг, передовых технологий, внедрению современных принципов и форм построения бизнеса во всех странах - участницах процесса. Сложившаяся китайская интеграционная формула предполагала углубленное сотрудничество восточноазиатских государств, когда креативная модернизация должна была перейти с национального на региональный уровень (Zhuang, 2010: 79). Китайские эксперты считают, что увеличение креативной составляющей модернизации в рамках региональной интеграции в конечном итоге будет определять ее эффективность. Здесь вполне реально смогли проявиться объективные возможности формирующегося единого экономического пространства Восточной Азии, которое должно было оказывать существенное влияние на обновление потенциала национальных экономик восточноазиатских стран через широкие взаимные инвестиции, консолидацию научно-исследовательских и опытно-конструкторских работ, реально создающих объективные условия для совместной инновационной деятельности.

Идея согласованной модернизации при лидерстве Китая могла бы оказаться привлекательной для государств Восточной Азии, поскольку позволяет осуществлять региональную интеграцию через механизмы равноправных соглашений и контрактов, приобретение привлекательных активов, учреждение совместных предприятий, включение национальных профильных компаний и исследовательских центров в работу на различных региональных уровнях. В данной связи на практике происходит фактическое сращивание развивающихся восточноазиатских экономик на глубоком микроэкономическом уровне (регионализация), что, скорее всего, обеспечит рост их внутренней взаимосвязанности и доходности, существенно расширит уверенно накапливающийся позитивный потенциал последующей широкой высокотехнологической модернизации (Yamamoto, 2007: 324-325). В сложных рамках китайской интеграционной формулы станет возможным решать проблемы, которые ранее было невозможно 
решить ни на основе двустороннего, ни на основе многостороннего сотрудничества. Определяющим предполагается сделать внутренний спрос при одновременном расширении взаимодействия с внешним миром, ставя целью повышение конкурентоспособности всего региона в целом. Подобный контекст подразумевает решение стратегической задачи преодоления общими усилиями чрезмерной экономической и социальной асимметрии, оказание адресной помощи менее развитым государствам Восточной Азии при условии их участия в совместных региональных интеграционных проектах в рамках единой системы перераспределения выгод и адекватной компенсации потерь.

Согласно международным оценкам, в масштабах восточноазиатской региональной экономики стоит объективная задача достижения гораздо большей согласованности в рамках преференциальных отношений интегрирующихся стран, затрагивающих ряд специальных соглашений, предписываемых многосторонними конвенциями о сотрудничестве в формате Всемирной торговой организации (BTO) (Yamazawa, 2008: 12). Чтобы как-то обеспечить справедливый баланс интересов всех государств Восточной Азии, тому же Китаю приходится совершенствовать существующую нормативно-правовую базу. Сложность решения названной проблемы больно бьет по малым и средним предприятиям практически во всех странах Восточноазиатского региона независимо от потенциала их экономик. Фактически в Восточной Азии формируется новый вид торгового протекционизма, который более экономически развитые государства активно используют против значительно менее развитых стран. Таким образом, внутрирегиональная интеграция, включая торговлю и движение капиталов, развивается крайне противоречиво: с одной стороны, растет либерализация национальных рынков в рамках многосторонних правил игры, а с другой - происходит фрагментация восточноазиатского экономического пространства в результате действия большого количества преференциальных торговых соглашений, отражающих скрытые тенденции в интеграционных процессах Восточной Азии (Zhuang, Jifeng, 2012: 111).

Китайская формула восточноазиатской интеграции содержит значительное количество убедительных аргументов в пользу важности усиления региональной составляющей. Руководство КНР полагает, что без создания собственной региональной группировки страна не справится с задачей устойчивого роста и не сможет в сжатые сроки осуществить высокотехнологичную модернизацию. Китай рассматривает Восточную Азию как свой собственный макрорегион, нуждающийся в его лидирующей роли. Китайские власти убеждены, что политическое сближение с Западом не гарантирует стране технологического прорыва, поскольку Запад смотрит на КНР не как на равноправного партнера, а как на потенциального конкурента, с которым нельзя делиться новыми знаниями (Катіуа, 2013: 14). Аля Китая восточноазиатский региональный рынок является безусловным приоритетом, но не по фактически достигнутым результатам (хотя и такие имеются), а с учетом его перспективного значения для развития в качестве расширенного внутреннего рынка.

\section{СПИСОК АИТЕРАТУРЫ}

Bono, Narihiro (2007) Higashi Ajia kyodotai no kochiku // Rimmei kokusai tiiki kenkyusyo, № 25 . Kyoto. P. 113-117). (На яп. яз.).

Boeisyo boei kenkyusyo. (2011) Tyugoku anzen hosyo repoto (Аоклад о гарантиях безопасности для Китая). Tokyo : National Institute for Defense Studies. 54 р. (На яп. яз.). 
Brink, T. (2012) Konfliktbelandene Abhängigkeiten: Wie der chinesische Aufstieg weltwirschaftliche Kräftekonstellationen verändert (German). Frakfurt am Main : VS Verlag. 643 s.

Brown, K. (2013) Contemporary China. Palgrave Macmillan. London. 232 p.

Cao, Y. (2015) Higashi Ajia no heiwateki hatten ni taisuru Tyugoku ni kitai sareru seisaku. Tokyo : Xiamen University Publishers. 318 р. (На яп. яз.).

Chen, Lung-chu (2015) Taiwan guojiage yanbian. Taibei daxue chubanshe. Oxford University Press. 99 р. (На кит. яз.).

Dent, C. M. (2008) East Asian Regionalism. London, New York : Routledge. 83 p.

Gehler, M., Rollinger, R. (2014) Chinesische Imperien // Imperien und Reiche in der Weltgeschichte / ed. by S. Fick, S. Pittl. Wiesbaden : Harrassowitz. 724 p. P. 515-535.

Helwig, N. (2015) Europe's New Political Engine: Germany's role in the EU's foreign and security policy. Konrad Adenauer Stiftung. The Finnish Institute of International Affairs. Helsinki. 224 p.

Hayashi, R. (1930) Koshi to Koshikyo. Osaka : Kobunsha. 1012 р. (На яп. яз.).

Juncer, J. C. (2014) Politische Leitlinen für die nächste Europäische Kommission (Deutch). Straßburg, 15. Juli 2014. 26 s.

Kamiya, M. (2013) Higashi Ajia tiiki titsujyo no doko // Kokusai mondai, №623. P. 12-20. (Ha яп. яз.).

Kojima, H. (2011) Higashi Ajia kyodotai to nittyu kyoryoku // Ajia kenkyu, № 3. P. 12-24. (Ha яп. яз.).

Matsuyi, K. (2011) Higashi Ajia kyodotai to Nihon / Tokubetsu tyosasitsu. 10 р. (На яп. яз.).

Mizuno, N. (2012) Higashi Ajia kyodotai ni muketa nittyukan no torikomu / Waseda daigaku kokusai kankei gakubu suppan. 5 р. (На яп. яз.).

Motegi, T. (2013) Higashi Ajia ni okeru dentoteki titsujyo no fumaeru ka // Kokusai mondai. № 623. Р. 42-52. (На яп. яз.).

Tanabe, S. (2005) Higashi Ajia kyodotai no koso. Kokuritsu kokkai tosshokan. Issue Briff. No. 489. Tokyo. 11 р. (На яп. яз.).

Sugimoto, Katsunori (2009) Futatsu no tikyu kankyo mondai to Higashi Ajia kyodotai // Rippo to kankyo. № 297. Tokyo. Р. 32-50. (На яп. яз.).

Tanaka, A. (2010) Nihon no Higashi Ajia gaiko senryaku / NIRA taidan sirizu. №54. Sogo kenkyu kaihatsu kiko. Tokyo daigaku suppan. Tokyo. 11 р. (На яп. яз.).

Terada, T. (2015) Japan-ASEAN Partnership in an Era of Multiple Regional Integration Frameworks. Doshisha University. Tokyo : Center for International Exchange Publishers. 98 p.

Watanabe, R. (2011) Kaiyo seiryoku to tairiku seiryoku - Higashi Ajia gaiko no kiso kenen // Takusyoku daigaku suppan. RIM. Vol. 7. № 24. Р. 19-30. (На яп. яз.).

Xia, G. (2006) Higashi Ajia kyodotai no kochiku. Kyoto : Mineruwa suppan. 344 р. (На яп. яз).

$\mathrm{Xu}$, M. (2003) Dongya jingji jiehe: Zhongguo de shijie he zhengce (Восточноазиатское экономическое единение: китайский мир и политика КНP) // Taipingyang Jingji Wenzhang. № 341. P. 4-14. (На кит. яз.).

Yafuku, N. (2015) Sindankai-o mukaeta Higashi Ajia / Ajia kenkyusyo sirizu. № 85. 247 p. (Ha яп. яз.).

Yamamoto, B. (2007) Higashi Ajia kyodotai no kotiku (Формирование Восточноазиатского сообщества) // Iwanami syoten. P. 324-325. (На яп. яз.).

Yamazawa, I. (2008) APEC to Higashi Ajia kyodotai (АТЭС и Восточноазиатское сообщество) // Kokusai boeki kenkyusyo no zassi. Hitotsubashi daigaku suppan. P. 3-14. (На яп. яз.).

Zhang, Jifeng (2012) Tyunichi keizai kyoryoku kankei no doko (Тенденции в китайско-японских экономических отношениях) // Hokuto Ajia kenkyu. № 22. Tokyo. P. 107-119. (На яп. яз.).

Zhang, Y. (2006) China and East Asian economic integration and cooperation // Journal of Economic Development. № 31 (2). P. 169-184.

Zhuang, G. (2010) Kochikutyu no Higashi Ajia keizai kyodotai to sono doko // Rimon daigaku nanyo kenkyusyo no suppan. Kokusai tiiki kenkyu, № 32. Р. 71-84. (На яп. яз.). 


\section{CHINESE PARADIGM OF EAST ASIAN INTEGRATION \\ V. I. BALAKIN \\ MOSCOW UNIVERSITY OF HUMANITIES}

American administration and Japanese government officially do not consider PRC as the main enemy but in practice almost all international experts see the powerful Chinese state growing into a serious competitor for the influence in the East Asian region. Among specialists the opinion is that the all-important factor for the USA and Japan is the necessity of having a clear conception of interrelations with China for the next 15-20 years. The regionalization in East Asia actuated its participants towards the search of counterpoises and attempts to create a certain balance with the help of harmonization of international relations.

The Chinese formula of East Asian integration contains a considerable number of convincing arguments in favour of the importance to strengthen the regional component. Japan, for example, is not ready to surrender at discretion of China and attempts to oppose the public opinion of almost all East Asian countries which feel acute anxiety over unpredictable consequences of the growing Chinese domination in the East Asian region. East Asian states keep a vigilant watch out for the dynamic of PRC' growing military potential, especially in its new quantitative and qualitative variants.

According to international experts' estimates, China by virtue of its obviously growing economic, demographic, military, and political potentials is becoming one of the powerful players on the Asian stage and in the long run will be able to effectively dominate all significant Asian affairs.

Keywords: PRC; China; Japan; regionalization; regional competition; regional leadership; East Asian integration; East Asian community

\section{REFERENCES}

Bono, N. (2007) Higashi Ajia kyodotai no kochiku. Rimmei kokusai tiiki kenkyusyo, no. 25. Kyoto. P. 113-117. (In Japanese).

Boeisyo boei kenkyusyo. (2011) Tyugoku anzen bosyo repoto. Tokyo, National Institute for Defense Studies. 54 p. (In Japanese).

Brink, T. (2012) Konfliktbelandene Abbängigkeiten: Wie der cbinesiscbe Aufstieg weltwirschaftliche Kräftekonstellationen verändert (German). Frakfurt am Main : VS Verlag. 643 p. (In Germ.).

Brown, K. (2013) Contemporary China. Palgrave Macmillan. London. 232 p.

Cao, Y. (2015) Higashi Ajia no beiwateki batten ni taisuru Tyugoku ni kitai sareru seisaku. Tokyo, Xiamen University Publishers. 318 p. (In Japanese).

Chen, Lung-chu (2015) Taiwan guojiage yanbian. Taibei daxue chubanshe. Oxford University Press. 99 p. (In Chinese).

Dent, C. M. (2008) East Asian Regionalism. London, New York : Routledge. 83 p.

Gehler, M., Rollinger, R. (2014) Chinesische Imperien. In: Imperien und Reiche in der Weltgeschichte / ed. by S. Fick, S. Pittl. Wiesbaden, Harrassowitz. 724 p. Pp. 515-535.

Helwig, N. (2015) Europe's New Political Engine: Germany's role in the EU's foreign and security policy. Konrad Adenauer Stiftung. The Finnish Institute of International Affairs. Helsinki. 224 p.

Hayashi, R. (1930) Kosbi to Kosbikyo. Osaka, Kobunsha. 1012 p. (In Japanese).

Juncer, J. C. (2014) Politische Leitlinen für die nächste Europäische Kommission (Deutch). Straßburg, 15. Juli 2014. 26 p. (In Germ.).

Kamiya, M. (2013) Higashi Ajia tiiki titsujyo no doko. Kokusai mondai, no. 623, pp. 12-20. (In Japanese).

Kojima, H. (2011) Higashi Ajia kyodotai to nittyu kyoryoku. Ajia kenkyu, no. 3, pp. 12-24. (In Japanese).

Matsuyi, K. (2011) Higashi Ajia kyodotai to Nibon / Tokubetsu tyosasitsu. 10 p. (In Japanese).

Mizuno, N. (2012) Higashi Ajia kyodotai ni muketa nittyukan no torikomu / Waseda daigaku kokusai kankei gakubu suppan. 5 p. (In Japanese).

Motegi, T. (2013) Higashi Ajia ni okeru dentoteki titsujyo no fumaeru ka. Kokusai mondai, no. 623 , pp. 42-52. (In Japanese). 
Tanabe, S. (2005) Higashi Ajia kyodotai no koso. Kokuritsu kokkai tosshokan. Issue Briff. No. 489. Tokyo. 11 p. (In Japanese).

Sugimoto, Katsunori (2009) Futatsu no tikyu kankyo mondai to Higashi Ajia kyodotai. Rippo to kankyo, no. 297, pp. 32-50. (In Japanese).

Tanaka, A. (2010) Nibon no Higasbi Ajia gaiko senryaku / NIRA taidan sirizu. №54. Sogo kenkyu kaihatsu kiko. Tokyo daigaku suppan. Tokyo. 11 p. (In Japanese).

Terada, T. (2015) Japan-ASEAN Partnership in an Era of Multiple Regional Integration Frameworks. Dosbisha University. Tokyo, Center for International Exchange Publishers. 98 p.

Watanabe, R. (2011) Kaiyo seiryoku to tairiku seiryoku - Higashi Ajia gaiko no kiso kenen. Takusyoku daigaku suppan. RIM. Vol. 7. № 24. P. 19-30. (In Japanese).

Xia, G. (2006) Higashi Ajia kyodotai no kochiku. Kyoto, Mineruwa suppan. 344 p. (In Japanese).

$\mathrm{Xu}$, M. (2003) Dongya jingji jiehe: Zhongguo de shijie he zhengce (Vostochnoaziatskoe ekonomicheskoe edinenie: kitaiskii mir i politika KNR). Taipingyang Jingji Wenzhang, no. 341, pp. 4-14. (In Chinese).

Yafuku, N. (2015) Sindankai-o mukaeta Higashi Ajia / Ajia kenkyusyo sirizu. № 85. 247 r. (In Japanese).

Yamamoto, B. (2007) Higashi Ajia kyodotai no kotiku (Formirovanie Vostochnoaziatskogo soobshchestva). Iwanami syoten, pp. 324-325. (In Japanese).

Yamazawa, I. (2008) ARES to Higashi Ajia kyodotai (ATES i Vostochnoaziatskoe soobshchestvo). Kokusai boeki kenkyusyo no zassi. Hitotsubashi daigaku suppan, pp. 3-14. (In Japanese).

Zhang, Jifeng (2012) Tyunichi keizai kyoryoku kankei no doko (Tendentsii v kitaisko-iaponskikh ekonomicheskikh otnosheniiakh). Hokuto Ajia kenkyu, no. 22, pp. 107-119. (In Japanese).

Zhang, Y. (2006) China and East Asian economic integration and cooperation. Journal of Economic Development, no. 31 (2), pp. 169-184.

Zhuang, G. (2010) Kochikutyu no Higashi Ajia keizai kyodotai to sono doko. Rimon daigaku nanyo kenkyusyo no suppan. Kokusai tiiki kenkyu, no. 32, pp. 71-84. (In Japanese).

Submission date: 06.06.2017.

Балакин Вячеслав Иванович - кандидат юридических наук, доцент кафедры регионоведения факультета международных отношений и туризма Московского гуманитарного университета. Адрес: 111393, Россия, г. Москва, ул. Юности, д. 5. Тел.: +7 (499) 374-55-90. Эл. адрес: viacheslavbalakin@rambler.ru

Balakin Vyacheslav Ivanovich, Candidate of Law, Associate Professor, Department of Regional Studies, Faculty of International Relations and Tourism, Moscow University for the Humanities. Postal address: 5, Yunosti St., Moscow, Russian Federation 111395. Tel.: +7 (499) 374-55-90. E-mail: viacheslavbalakin@rambler.ru 